\title{
STRATEGI PENGEMBANGAN PROGRAM KEUANGAN MIKRO DALAM KERANGKA TANGGUNG JAWAB SOSIAL PT NEWMONT NUSA TENGGARA DIKABUPATEN SUMBAWA BARAT
}

\section{The Strategy of Developing Microfinance Program Implemented by PT Newmont Nusa Tenggara in Running Its Corporate Social Responsibility Program at West Sumbawa Regency}

\author{
Syamsul Bakhri*), Ekawati Sri Wahyuni, Pudji Muljono \\ Departemen Sains Komunikasi dan Pengembangan Masyarakat, Fakultas Ekologi Manusia IPB \\ *) email: syamsul.bakhri@nnt.co.id
}

\begin{abstract}
This research aims at (1) studying the microfinance program run by and the organization of Yayasan Olat Parigi/ Olat Parigi Foundation (YOP) as part of PT Newmont Nusa Tenggara's Corporate Social Responsibility; (2) formulating the development strategy for the organization and microfinance program for self-reliance and sustainability. This study employs qualitative approach and supported by quantitative approach. The study shows that: Firstly, theorganizational management of YOP constitutes two periods of services namely YOP Part I and YOP Part II. In comparison, the organizional management and program run by YOP Part II is better than YOP Part I as demonstrated by a number of improvements in some aspects including management of administration, human resources, budgeting, microfinance program and business unit strategic. However, this study has identified weaknesses in the area of self-reliance, resilience, and sustainability as shown in high dependency of the foundation to PTNNT (both in financing and facilitation). The Microfinance program has been implemented as per applicable SOP where clients are facilitated to obtain easy access and capability to fulfill the requirements, simplified procedures, right on target, up to date, consistent with characteristics of the locals and most importantly it provides more benefits for the locals. A number of challenges identified in running the microfinance program include high number of Non-Performing Loan, limited financing scheme, and inadequate assistance and/or capacity to the program beneficiaries. Secondly, the development strategy for organizational and microfinance programs shall be improved to reach a self-reliance, resilience, and sustainability of the program through implementation of bounding, bridging, and creating/ networking strategies.
\end{abstract}

Keywords: CSR,development strategy, institution, microfinance

\section{PENDAHULUAN}

Tanggung Jawab Sosial Perusahaan (TJSP) atau Corporate Social Responsibility (CSR) lebih menekankan kewajiban moral, bukan merupakan strategi bisnis semata. Maknanya bahwa tidak ada hubungannya secara langsung antara TJSP dengan mencari keuntungan perusahaan. TJSP memang ditujukan untuk menunjukkan reputasi perusahaan di mata masyarakat dunia bahwa perusahaan atau bisnis benar-benar memiliki tanggung jawab moral terhadap lingkungan dan masyarakat untuk mendorong terwujudnya pembangunan sosial (Susetiawan, 2012).

PTNNT adalah perusahaan tambang tembaga dan emas multi nasional yang beroperasi di wilayah Kabupaten Sumbawa Barat (KSB) atas dasar Kontrak Karya dengan Pemerintah Republik Indonesia sejak Tahun 1986. PTNNT mempunyai visi: "Kita akan menjadi perusahaan tambang yang paling dihargai dan dihormati melalui pencapaian kinerja terdepan dalam industri tambang". Visi tersebut kemudian dijabarkan ke dalam misi: "Kita akan membangun perusahaan tambang yang berkelanjutan, yang mampu memberikan laba tertinggi kepada para pemegang saham dan menjadi yang terdepan dibidang keselamatan kerja, perlindungan lingkungan, dan tanggung jawab sosial"

Selanjutnya,kebijakanTJSPtersebutdijabarkankedalamRencana Strategis (Renstra) lima tahunan Program Pengembangan Masyarakat atau Community Development (Comdev) 20142018. Secara substantif, Renstra Comdev PTNNT berisi visi, misi, sasaran misi, landasan (nilai-nilai dan prinsip dasar yang dianut), isu-isu strategis, dan bidang utama program yang meliputi bidang ekonomi, kesehatan, pendidikan, sosial budaya, dan lingkungan.

Program Comdev adalah salah satu wujud implementasi dari Kebijakan TJS PTNNT. Tujuan utama program tersebut adalah membantu meningkat kualitas hidup dan kesejahteraan masyarakat sekitar melalui berbagai program di bidang 
ekonomi, kesehatan, pendidikan, sosial budaya dan keagamaan, serta pelestarian lingkungan.Implementasi program Comdev bidang ekonomi ditopang oleh dua "pilar" utama, yaitu Yayasan Pembangunan Enomi Sumbawa Barat (YPESB) dan YOP. YPESB berperanan dalam melakukan identifikasi potensi, penguatan, pengembangan, dan pendampingan usaha lokal.Sedangkan YOP lebih fokus pada aspek permodalan atau pembiayaan usaha mikro.

Visi YOP adalah "menjadikan YOP sebagai lembaga yang mandiri dan berkelanjutan, memiliki sumberdaya manusia yang kapabel dan profesional dalam mengembangkan program secara partisipatif dan inovatif serta mengembangkan kemitraan yang konstruktif'.Rumusan visi tersebut kemudian dijabarkan dalam rumusan misi (1) mendorong tata kelola kelembagaan yang transparan dan akuntabel; (2) meningkatkan kapasitas sumberdaya manusia menuju tenaga yang kapabel dan profesional dibidangnya; (3) mendorong program pemberdayaan masyarakat yang strategis dan inovatif; dan (4) mendorong terwujudnya kemitraan yang konstruktif dan kesetaraan.

Selama periode 1999-2014, YOP telah mengelola danaTJS PTNNT rata-rata Rp 5 milyar per tahun. Dana tersebut digunakan untuk program dan operasional.Selain itu, YOP juga mendapatkan pembinaan/ pendampingan langsung dari PTNNT.Periode 1999-2010 YOP mengelola beberapa program, namun sejak tahun 2011hingga saat ini, YOP fokus mengelola dua program utama, yaitu (1) Keuangan Mikro dan (2) pengembangan unit bisnis strategis. Pada periode 2011-2013, YOP telah menyalurkan dana untuk Keuangan Mikrosebesar Rp 5,8 milyarkepada 1,696 nasabah yang tersebar di delapan kecamatan yang ada di wilayah KSB.

Mencermati kebijakan TJS PTNNT terhadap YOP, pola dan periode kemitraan, serta besaran dana yang dikelola, maka muncul pertanyaan utama kajian (main reseach question) tentang "bagaimana pengelolaan dan strategi pengembangan kelembagaan dan pogram Keuangan Mikro dalam kerangka TJS PTNNT?"

Untuk menjawab pertanyaan tersebut, tujuan kajian ini adalah (1) mengkaji pengelolaan kelembagaan dan program Keuangan Mikro YOP, dan (2) merumuskan strategi pengembangan kelembagaan dan program Keuangan Mikrodalam kerangka TJS PTNNT.

\section{TINJAUAN PUSTAKA}

\section{Corporate Social Resposibility (CSR)}

Wibisono(2007)mendefinisikan CSR sebagai tanggung jawab perusahaan kepada pemangku kepentingan untuk berlaku etis, meminimalkan dampak negatif dan memaksimalkan dampak positif yang mencakup aspek ekonomi sosial dan lingkungan (triple bottom line) dalam rangka mencapai tujuan pembangunan berkelanjutan. Nursahid(2006) mendefinisikan CSR sebagai tanggung jawab moral suatu organisasi bisnis terhadap kelompok yang menjadi stakeholder-nya yang terkena pengaruh baik secara langsung ataupun tidak langsung dari operasi perusahaan.

Kottler etal.(2005) memberikan definisi CSR sebagai sebuah komitmen untuk meningkatkan kesejahteraan masyarakat melalui praktik bisnis dan kontribusi sumberdaya perusahaan secara sukarela. Elemen utama definisi ini adalah sukarela, bukan kegiatan bisnis yang menjadi kewajiban hukum atau yang memiliki sifat moral atau etis. Selanjutnya, Carroll (1979) menawarkan definisi berikut: "Tanggung jawab sosial bisnis mencakup ekspektasi ekonomi, legal, etika dan diskriner yang masyarakat miliki terhadap organisasi pada suatu waktu".

Sedangkan ISO 26000: 2010 Guidance on Social Responsibility: CSRadalahtanggungjawabsebuahperusahaan atas dampak keputusan dan kegiatannya terhadap masyarakat dan lingkungan, melalui perilaku yang transparan dan etisyang berkontribusi bagi pembangungan berkelanjutan, kesehatan dan kesejahteraan masyarakat, dengan mempertimbangkan pengharapan pemangku kepentingan, dilaksanakan dengan mematuhi hukum yang berlaku dan sesuai dengan norma dan perilaku internasional, dan diintegrasikan di seluruh perusahaan dan dipraktikkan dalam hubungan-hubungan perusahaan.

Penerapan CSR dangat dipengaruhi oleh pandangan perusahaan mengenai CSR. Wibisono (2007) menjelaskan beberapa cara pandang perusahaan terhadap CSR, yaitu: (1) Sekedar basa-basi atau keterpaksaan. Perusahaan mempraktekkan CSR karena external driven (faktor eksternal), environmental driven (karena terjadi masalah lingkungan dan reputation driven (karena ingin mendongkrak citra perusahaan); (2) Sebagai upaya memenuhi kewajiban (compliance); (3) CSR diimplementasikan karena adanya dorongan yang tulus dari dalam (internal driven). CSR adalah konsep moral dan etis yang berciri umum, oleh karena itu pada tataran praktisnya harus dialirkan ke dalam programprogram kongkrit. Program Corporate Social Responsibility (CSR) meliputi tujuan, sosialisasi, pelaksanaan, manfaat dan dampak.

\section{Pengembangan Masyarakat (Community Development)}

Pengembangan Masyarakat atauCommunity Development (CD)adalah konsep dasar yang menggarisbawahi sejumlah istilah yang telah digunakan sejak lama seperti community resource development, rural area development, community economic development, rural revitalization, dan community based development. CD menggambarkan dua makna penting dari dua konsep, yaitu: Community bermakna kualitas hubungan sosial, dan Development bermakna perubahan ke arah kemajuan yang terencana dan bersifat gradual. Makna ini penting untuk arti pengembangan masyarakat yang sesungguhnya (Blackburn, 1989 dalam Nasdian , 2014).

Pengembangan masyarakat didasari sebuah cita-cita bahwa masyarakat bisa dan harus mengambil tanggung jawab dalam merumuskan kebutuhan, mengusahakan kesejahteraan, menangani sumber daya, dan mewujudkan tujuanhidup sendiri. Pengembangan masyarakat diarahkan untuk membangun supportive communities, yaitu sebuah 
struktur masyarakat yang kehidupannya didasarkan pada pengembangan dan pembagian sumberdaya secara adil serta adanya interaksi sosial, partisipasi, dan upaya saling mendorong antara satu dengan yang lain (Zubaedi, 2013).

Lebih lanjut, menurut Zubaedi (2013) bahwa pengembangan masyarakat adalah upaya mengembangkan sebuah kondisi masyarakat secara berkelanjutan dan aktif berlandaskan prinsip-prinsip keadilan sosial dan saling menghargai. Van Beers dan Colley (1972) dalam Nasdian (2014) mendefinisikan pengembangan masyarakat sebagai upaya "membantu diri sendiri" untuk meningkatkan standard dan kualitas hidup masyarakat di pedesaan.

"Community Development has been variously defined as a philosophy, a program, a method, or a movement. Community development defined as 'assisted self-help' to raise the standard of living and the quality of life in the rural areas".

Sanders (1958) dalam Nasdian (2014) menunjukan bahwa pengembangan masyarakat dipandang sebagi suatu proses, metode, program atau gerakan. Selanjutnya, Robert Chambers dalam Kartasasmita (1997) berpendapat bahwa pemberdayaan masyarakat adalah sebuah konsep pembangunan ekonomi yang merangkum nilai-nilai sosial. Konsep ini mencerminkan paradigma baru pembangunan, yakni bersifat people centered, participatory, empowering and sustainable. Konsep ini lebih luas dari semata-mata memenuhi kebutuhan dasar, atau menyediakan mekanisme untuk mencegah proses pemiskinan lebih lanjut (safety net).Dalam menginterpretasikan pendekatan-pendekatan pengembangan masyarakat muncul keragaman yang dilatarbelakangi oleh berbagai faktor, antara lain perbedaan nilai budaya dan tujuan dari berbagai kalangan dalam menggunakan istilah tersebut (Nasdian, 2014).

Pengembangan masyarakat sebagai perencanaan sosial perlu berlandaskan pada asas-asas, yaitu komunitas dilibatkan dalam setiap proses pengambilan keputusan, mensinergikan strategi komprehensif pemerintah, pihak-pihak terkait dan partisipasi warga, membuka akses warga atas bantuan profesional, teknis, fasilitas, serta insentif lainnya agar meningkatkan partisipasi warga, dan mengubah perilaku profesional agar lebih peka pada kebutuhan, perhatian dan gagasan warga komunitas. Prinsip-prinsip Community Developmentdibagi dalam beberapa bagian penting, yaitu ekologi, keadilan sosial, nilai-nilai lokal, proses, dan globallokal.(Ife, 2002).

\section{Keuangan Mikro (Microfinance)}

Secara terminologi, Keuangan Mikro adalah penyediaan layanan keuangan untuk kalangan berpenghasilan rendah, termasuk konsumen dan wiraswasta, yang secara tradisional tidak memiliki akses terhadap perbankan dan layanan terkait. Keuangan Mikro merupakan pembiayaan dengan skala mikro.Makna "micro" dalam dalam konteks ini berkaitan dengan nilai transaksi dan kapasitas keuangan nasabah yang umumnya masuk ke dalam kategori miskin seperti yang dirumuskan oleh United Nations Capital Development Fund
(UNCDF), Consultative Group to Assist the Poor (CGAP), dan Asian Development Bank (ADB):

"microfinancerefers to loans, savings, insurance, transfer services and other financial products targeted at lowincome clients".

Kata "Micro" juga merujuk kepada "inferiority" atau keterbatasan, yaitu inferioritas dari masyarakat miskin (the poor)yang sulit atau terbatas aksesnya kepada pelayanan jasa keuangan/ perbankan. Definisi lainnya yang lebih rinci dirumuskan oleh Robinson (2001) dari The Word Bank dalam bukunya The Microfinance Revolution: Sustainable Finance for the poor, Volume I \& II sebagai berikut :

"microfinance is small-scale financial services provided to people who farm or fish or herd; who operate small or microenterprises where goods are produced, recycled, repaired, or traded; who provide services; who work for wages or commissions; who gain income from renting out small amounts of land, vehicles, draft animals, or machinery and tools; and to other individuals and groups at the local levels of developing countries, both rural and urban.".

Dari berberapa definisi tersebut di atas, menunjukkan bahwa secara garis besar Keuangan Mikro mengandung tiga elemen utama yang membedakannya dengan sistem intermediasi keuangan lainnya seperti perbankan, yaitu (1) batasan transaksi, (2) segmentasi pasar, dan (3) tujuan. Pada umumnya Keuangan Mikro di Indonesia dikenal dengan Usaha Mikro, Kecil dan Menengah (UMKM). Dari statistik dan riset yang dilakukan, UMKM mewakili jumlah kelompok usaha terbesar. UMKM telah di atur secara hukum melalui Undang-undang Nomor 20 Tahun 2008 tentang Usaha Mikro, Kecil dan Menengah (UMKM).

Oleh karena Keuangan Mikro dianggap mempunyai peranan strategis dalam upaya pengentasan kemiskinan terutama di negara-negara miskin dan berkembang, maka upaya pengembangan terus dilakukan oleh pakar dan lembaga keuangan internasional dalam rangka pengelolaan keuangan mikro berkelanjutan, antara lain dilakukan oleh CGAP yang mengembangkan prinsip-prinsip kunci biasa dikenal dengan Key Principles of Microfinanceberisi 11 butir prinsip pokok, yaitu:

(1) Masyarakat miskin membutuhkan aneka ragam jasa keuangan, tidak hanya tabungan;

(2) Keuangan mikro adalah instrument yang berdayaguna untuk memerangi kemiskinan;

(3) Keuangan mikro artinya membangun system keuangan untuk melayani masyarakat miskin;

(4) Keberlanjutan keuangan sangat diperlukan agar mampu menjangkau orang miskin dalam dalam jumlah besar;

(5) Keuangan mikro itu mengenai pembangunan lembaga keuangan lokal yang permanen;

(6) Kredit mikro tidak selalu merupakan jawaban;

(7) Pembatasan suku bunga bisa merugikan akses masyrakat miskin terhadap jasa keuangan;

(8) Peran pemerintah adalah sebagai pemberi kemudahan, 
bukan sebagai penyedia jasa keuangan secara langsung;

(9) Subsidi donor harus bersifat melengkapi, tidak bersaing dengan modal sektor swasta;

(10) Kurangnya kemampuan atau kepasitas kelembagaan dan sumberdaya manusia adalah kendala kunci), dan

(11) Pentingnya transparansi keuangan dan jangkauan)

Secara empiris, efektivitas dari intervensi Keuangan Mikro memberikan dampak yang positif terhadap rumah tangga. Secara umum mekanisme dampak tersebut dapat dijelaskan dan digambarkan sebagai berikut: Pertama, akses keuangan yang berkelanjutan merupakan faktor produksi penting dalam kegiatan ekonomi masyarakat miskin yang dalam hal ini menghasilkan double impact yaitu pendapatan dan penyerapan tenaga kerja. Kedua, adanya jaminan pembiayaan mendorong pengusaha mikro mengambil keputusan bisnis jangka panjang dan melakukan investasi yang menguntungkan. Ketiga, efektivitas intervensi Keuangan Mikroyang dijelaskan sebelumnya telah mendorong berbagai inisiatif mengembangkan produk dan jasa keuangan lainnya untuk melayani masyarakat miskin, antara lain housing microfinance.

Implementasi kebijakan TJS PTNNT melalui program Comdev bidang ekonomi melahirkan beberapa program, antara lain Keuangan Mikro. Program dikelola oleh YOP dan eksistensinya diharapkan mampu menjadi bagian dari solusi terhadap salah satu kendala yang dihadapi usaha mikro-kecil-menengah yaitu keterbatasan modal usaha. Dalam upaya mensukseskan program tersebut, PTNNT melalui YOP telah memberikan dukungan penuh pada aspek pendanaan, pendampingan, dan fasilitas penunjang program lainnya.

Dukungan PTNNT telah memberikan pengaruh kuat terhadap eksistensi kelembagaan YOP selaku institusi pengelola di satu sisi, sementara menjadi sebuah pertanyaan besar jika dilihat dari aspek kemandirian dan keberlanjutan pada sisi lainnya. Saat ini, eksistensi dan keberlanjutan Program Keuangan Mikro sangat ditentukan oleh eksistensi kelembagaan YOP itu sendiri. Terkait hal tersebut, perlu dilakukan kajian mendalam dan menyeluruh terhadap aspek kelembagaan, guna merumuskan strategi yang tepat bagi pengembangan aspek tersebut yang juga berarti pengembangan program secara menyeluruh melalui pendekatan partisipatif.

Mengandalkan dukungan PTNNT saja tentu belum cukup bagi berkembang dan sustainabilitas kelembagaan dan program, namun harus ditunjang oleh faktor ensensial lainnya yaitu pelibatan peran serta (partisipasi) masyarakat yang dalam kontek pengembangan masyarakat merupakan salah satu prinsip utama yang harus ada. Partisipasi masyarakat idealnya selalu muncul dalam setiap tahapan program, mulai dari tahap perencanaan, implementasi, monitoring, dan evaluasi.

Secara empiris, program pembangunan atau pengembangan masyarakat yang ada kaitannya dengan TJSP, akan menimbulkan persepsi masyarakat yang berbeda jika dibandingkan program pemerintah atau pihak ketiga nonTJSP, misalnya saja Lembaga Swadaya Masyarakat(LSM). Oleh karena program Keuangan Mikro yang dikelola YOP tersebut terkait erat dengan TJSP, maka persepsi masyarakat terhadap kelembagaan maupun program merupakan salah satu variabel yang perlu dikaji. Ketiga variabel tersebut tentunya memberikan kontribusi bagi kinerja program Keuangan Mikro YOP secara keseluruhan.

Kajian tentang pengelolaan kelembagaan dan kinerja Keuangan MikroYOPadalahkunciutama dalammerumuskan strategi pengembangan program ke depan. Strategi yang dirumuskan, diharapkan dapat menjadi rujukan/ referensi bagi upaya perbaikan dan pengembangan, sehingga akan melahirkan program Keuangan Mikro berkelanjutan yang dicirikan oleh kelembagaan yang kuat dan mandiri, adanya partisipasi masyarakat dan stakeholders dalam pengelolaan program yang resultansinya dapat meningkatkan manfaat ekonomi bagi masyarakat sekitar

\section{METODE PENELITIAN}

Kajian dilakukan di wilayah Kecamatan Sekongkang KSB.Dalam konteksTJSP, lokasi ini dipilih karena operasi tambang tembaga dan emas PTNNT berada dalam wilayah ini. Pelaksanaan kajian dilakukan pada Bulan Juli sampai Desember 2014.

Secara garis besar kajian ini menggunakan pendekatan kualitatif yang ditunjang oleh kuantitatif. Pendekatan kualitatif digunakan untuk mendapatkan, mengeksplorasi/mengelaborasi data/informasi terkait dengan TJS PTNNT, Program Keuangan Mikro YOP dan permasalahan yang dihadapi, pengelolaan kelembagaan YOP dan perancangan strategis. Pendekatan kuantitatif digunakan untuk mendapatkan data-data antara lain terkait TJS PTNNT, beneficeries dan anggaranKeuangan Mikro.Data ini diperlukan untuk menunjang data kualitatif yang didapatkan.

Pemilihan informan ditentukan secara purposive dengan pertimbangan dan tujuan tertentu, yaitu mereka yang dipilih merupakan stakeholdersatau pihak yang terlibat dalam pengelolaan program atau dianggap mempunyai hubungan, pengetahuan, pemahaman, dan autoritas dalam

Tabel 1. Unsur dan jumlah informan kajian

\begin{tabular}{llc}
\hline No & \multicolumn{1}{c}{ Informan } & $\begin{array}{c}\text { Jumlah } \\
\text { (orang) }\end{array}$ \\
\hline 1 & Managemen PTNNT & 1 \\
2 & Pendamping program PTNNT & 1 \\
3 & Pengurus YOP & 1 \\
4 & Koordinator Program & 1 \\
& MicrofinanceYOP & \\
5 & Supervisor Program YOP & 1 \\
6 & Kepala desa & 3 \\
7 & Tokoh masyarakat & 3 \\
8 & Beneficeries Program Keuangan & 12 \\
& Mikro & 23 \\
\hline Total & \\
\hline
\end{tabular}


Tabel 2. Matrik pengumpulan data tematik, tehnikpengambilan, dan sumber informasi/ data.

\begin{tabular}{|c|c|c|c|}
\hline No & Tematik & $\begin{array}{c}\text { Teknik } \\
\text { pengambilan } \\
\text { data }\end{array}$ & Sumber data/informasi \\
\hline \multirow[t]{3}{*}{1} & $\begin{array}{l}\text { Pengelolaan dan permasalahan Program } \\
\text { Microfinance }\end{array}$ & $\begin{array}{l}\text { Studi } \\
\text { Dokumen } \\
\text { (SD) }\end{array}$ & $\begin{array}{l}\text { PTNNT, YOP, dan sumber lain yang dianggap } \\
\text { relevan. }\end{array}$ \\
\hline & & $\begin{array}{l}\text { Wawancara } \\
\text { Mendalam } \\
(\mathrm{WM})\end{array}$ & $\begin{array}{l}\text { Managemen dan pendamping PTNNT, } \\
\text { Pengurus YOP, koordinator dan supervisor } \\
\text { program, dan operasional pembiayaan (OP). }\end{array}$ \\
\hline & & $\begin{array}{l}\text { Focus Group } \\
\text { Discussion } \\
\text { (FGD) }\end{array}$ & Beneficiaries program \\
\hline 2 & Kelembagaan pengelola program (YOP) & $\begin{array}{l}\text { Wawancara } \\
\text { Mendalam } \\
(\mathrm{WM})\end{array}$ & $\begin{array}{l}\text { Managemen dan pendamping PTNNT, } \\
\text { pengurus YOP, koordinator dan supervisor } \\
\text { program microfinance, kepala desa, tokoh } \\
\text { masyarakat }\end{array}$ \\
\hline 3 & Strategi pengembangan & $\begin{array}{l}\text { SWOT } \\
\text { Analysis, dan } \\
\text { observasi }\end{array}$ & $\begin{array}{l}\text { SWOT: Pendamping PTNNT, Pengurus YOP, } \\
\text { koordinator, supervisor OP-YOP, dan nasabah. } \\
\text { Observasi: OP-YOP dan peneliti }\end{array}$ \\
\hline
\end{tabular}

program Keuangan Mikro YOP (Tabel 1). Data-data yang peroleh dari para informan dalamTabel 1 meliputi data-data terkait pengelolaan programKeuangan Mikro, permasalahan-permasalahan yang dihadapi oleh lembaga pengelola (YOP), dan strategi pengembangan ke depan (Tabel 2).

Beberapa tehnik yang digunakan pada proses pengumpulan adalah (1) studi dokumen terkait Keuangan Mikro YOP, aturan, kebijakan, SOP, hasil studi, laporan proses, serta capaian program, (2) in-dept interview dan FGD terkait TJS PTNNT, YOP, dan program Keuangan Mikro, (3) Analisis SWOT untuk perancangan strategi, dan (4) Observasi, terkait sosial ekonomi (misalnya kondisi usaha) dan fenomena terkait lainnya di lapangan.

Menurut Miles and Huberman (1984) seperti dikutip Sugiyono (2013) mengemukakan bahwa aktivitas dalam analisis data kualitatif dilakukan secara interaktif dan berlangsung secara terus menerus sampai tuntas, hingga datanya jenuh. Aktivitas dalam analisis data yaitu data reduction, data display, dan conclusion drawing/verification (Gambar 2).

Data yang diperoleh di lapangan jumlahnya cukup banyak, untuk itu perlu dicatat secara teliti dan rinci. Data yang dikumpulkan kemudian di reduksi (data reduction).Setelah data direduksi, langkah selanjutnya adalah menampilkan data (data display) dalam bentuk uraian singkat, bagan, hubungan antar kategori, flow chart dan sejenisnya. Terakhir adalah penarikan kesimpulan dan verifikasi.

\section{Perancangan Strategi/Program Aksi}

Perancangan strategi/ program aksi yang dilakukan adalah merupakan rangkaian atau tahapan yang tidak terpisahkan dari kajian yang dilakukan. Oleh karenanya metode perancangan strategi/ program aksi sangat ditentukan atau berkaitan dengan hasil kajian.Hasil kajian melahirkan kesimpulan dan rekomendasi. Kesimpulan dan rekomendasi tersebut kemudian dikomunikasikan kembali kepada sebagian stakeholders terkait yang telah dilibatkan dalam kajian untuk kemudian bersama-sama merumuskan perancangan strategi/ program aksi.

MetodePerancangan.Perumusanstrategimenggunakan pendekatan partisipatif dengan menggunakan metode FGD dan Analisis SWOT.Perancangan strategi kebijakan menggunakan rekomendasi dan diskusi khusus dengan stakeholders terkait. Partisipan Perancangan. Partisipan perancangan terdiri dari unsur-unsur (1) managemen PTNNT; (2) pendamping program PTNNT; (3) pengurus YOP; (4) koordinator program; (5) supervisor program; (6) Operasional Pembiayaan (OP); penerima manfaat program; (7) pemerintah desa; (8) tokoh masyarakat; (9) NGO, dan (10) Akademisi.

Proses Perancangan. Proses perancangan strategi dimulai dari mengidentifikasi dan merumuskan permasalahan dari hasil kajian. Selanjutnya dilakukan SWOT Analisys faktor internal dan eksternal.Analisis faktor internal dimaksudkan untuk menemukan kekuatan (strength) dan kelemahan (weakness).Sedangkan analisis faktor eksternal dimaksudkan untuk mengidentifikasi peluang yang ada (opportunity), dan ancaman yang dihadapi (threat). Selanjutnya menyusun strategi dengan mengawinkan faktor internal dan eksternal yang melahirkan strategi SO (Strength-Opportunity), ST (Strength-Threat), WO (Weakness-Opportunity), dan WT (Weakness-Threat) .

\section{Pengelolaan Kelembagaan YOPdan Program Keuangan Mikro}

\section{Community Development PTNNT}

Wujud implementasi kebijakan TJS PTNNT adalah Program 


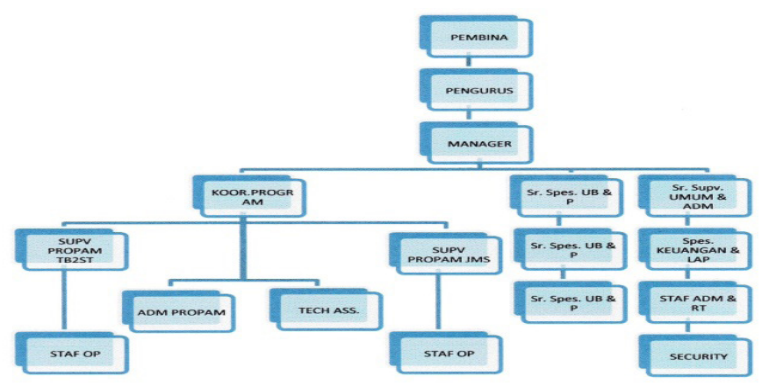

Gambar 3. Struktur organisasi YOP

Comdev yang merujuk kepada Renstra TJSP tahun 20142018.Renstra tersebut memuat visi, misi, tujuan dan program strategis, serta cakupan program. Visi TJS PTNNT "kita akan menjadi perusahaan yang paling dihargai dan dihormati dalam industri pertambangan Indonesia melalui pencapaian kinerja terdepan di bidang tanggung jawab sosial".Selanjutnya, rumusan misi untuk pencapaian misinya adalah "kita akan mengembangkan Program Tanggung Jawab Sosial yang efektif, berkelanjutan, partisipatif, dan berkemitraan yang mendukung tercapainya peningkatan kesejahteraan dan kemandirian masyarakat". Di bidang ekonomi, tujuan strategis yang ingin dicapai adalah "membantu pemerintah dalam meningkatkan pendapatan dan kesejahteraan masyarakat melalui penciftaan kesempatan kerja dan berwirausaha, terutama dalam sektor yang tidak berhubungan langsung dengan kegiatan tambang.'Peningkatan ekonomi masyarakat, selain fokus pada pengembangan pertanian, peternakan dan pariwisata, bantuan terhadap usaha mikro kecil juga dilakukan dalam bentuk pembukaan akses modal ke lembaga keuangan mikro dan pelatihan tehnis produkasi dan jaringan usaha (Renstra TJSP PTNNT tahun 2014-2018).

Program Comdev PTNNT di bidang ekonomi melingkupi wilayah KSB, dengan fokus utama pada tiga kecamatan di wilayah Lingkar Tambang, yaitu Kecamatan Sekongkang, Maluk, dan Jereweh sesuai arahan Renstra Comdev PTNNT tahun 2009-2013. Dalam implementasinya, Program Comdev menggunakan pendekatan/pola kemitraan pada semua bidang program, termasuk ekonomi.Kelembagaan ekonomi yang menjalin kemitraan dengan Program Comdev antara lain YPESB dan YOP.

\section{Yayasan Olat Parigi (YOP)}

YOP mengelola sebagian dana CSR PTNNT untuk tujuan pemberdayaan/pengembangan masyarakat bidang ekonomi. Proses pembentukan YOP difasilitasi oleh PTNNT. Secara sosial, berdirinya YOP merupakan respon masyarakat wilayah lingkar tambang terhadap eksistensiPTNNT di wilayah tersebut. Hal iniditegaskan oleh salah seorang tokoh masyarakat yang terlibat dalam proses pembentukan YOP sebagai berikut:

“...latar belakang berdirinya (YOP) itu diilhami oleh keberadaan PTNNT karena akan banyak dana yang harus disalurkan ke masyarakat. Oleh karena itu, kami bersamabeberapa kepala desa dipandang perlu untuk mendirikan yayasan yang akan mengelola dana hibah
PTNNT dan saya sangat setuju dengan ide tersebut". (HDr 2015)

Terkait latar belakang dan tujuan pembentukan YOP juga diperkuat oleh penyataan salah seorang tokoh masyarakat sebagai berikut:

"Sepengetahuan saya YOP itu berdiri pada tahun 1999 atau 2000 atas inisiasi PTNNT dengan melibatkan beberapa tokoh masyarakat dengan tujuan sebenarnya untuk membantu PTNNT dalam pengelolaan anggaran pemberdayaan masyarakat”. (ANs 2015)

Komposisi Dewan Pendiri YOPterdiridari satu orang perwakilan Kecamatan dan lima orang perwakilanmasingmasing desa. Mencermati sejarah pendiriannya, maka jelaslah bahwa eksistensi YOP akan sulit dipisahkan dari "kepentingan" PTNNT meskipun secara kelembagaan, YOP merupakan sebuah lembaga otonom yang dapat mengatur dirinya sendiri.

\section{Struktur Organisasi}

Staf YOP berjumlah 32 orang, termasuk 3 orang pengurus yang sekaligus sebagai karyawan atau pelaksana program. Jumlah tersebut merupakan hasil rasionalisasi dimana sebelumnya berjumlah 43 orangdengan tingkat pendidikan mulai dari Sekolah Dasar hingga Perguruan Tinggi (Gambar 3).

\section{Program YOP}

Pengurus dan Pendamping YOPmempunyai terminologiYOP Jilid I (Tahun 1999-2010) dan YOP Jilid II (2011-sekarang). Salah satu perbedaan yang mencolok dari sisi program adalah fokus dan pola pengelolaanKeuangan Mikro YOP(selengkapnya dibahas dalan sub bab isu strastegis), seperti dijelaskan salah seorang Petugas Lapangan (PL) YOP:

"YOP jilid I strukturnya cukup sederhana yaitu koordinator, bendahara dan PL. Namun di Jilid II ada perubahan yaitu pendamping dari PTNNT, pengurus, supervisor, administrasi dan OP”. (SWl 2014).

Penjelasan tersebut merujuk kepada meknisme seleksi penentuan warga masyarakat yang layak menjadi penerima

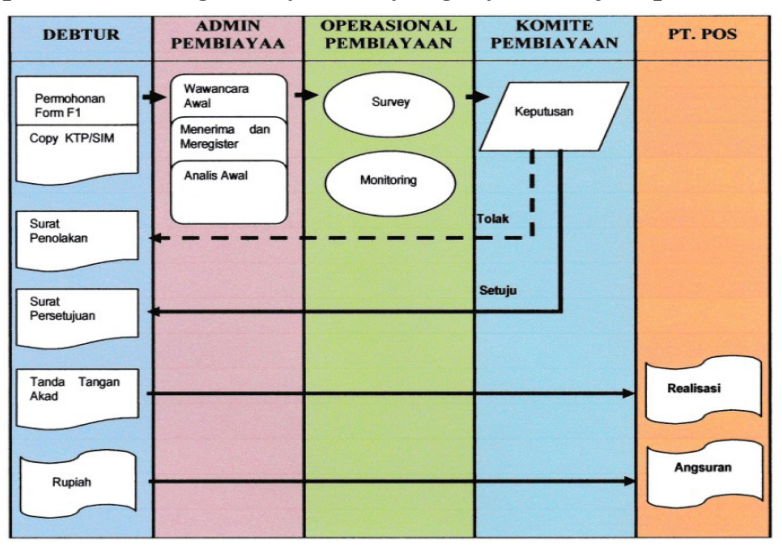

Gambar 4. Prosedur program keuangan mikro YOP 
Tabel 3. Realisasi program keuangan mikro YOP per kecamatan tahun 2011-2014

\begin{tabular}{llrrrr}
\hline No & $\begin{array}{c}\text { Keca- } \\
\text { matan }\end{array}$ & $\begin{array}{c}\text { Jumlah } \\
\text { realisasi } \\
\text { (kali) }\end{array}$ & \% & Nilai (Rp) & \multicolumn{1}{c}{$\%$} \\
\hline 1 & $\begin{array}{l}\text { Sekong- } \\
\text { kang }\end{array}$ & 377 & 22.2 & $1,654,500,000$ & 28.6 \\
2 & Jereweh & 276 & 16.3 & $1,078,000,000$ & 18.7 \\
3 & Maluk & 327 & 19.3 & $1,158,000,000$ & 20 \\
4 & Tali- & 306 & 18 & $709,000,000$ & 12.3 \\
& wang & 121 & 7.1 & $283,500,000$ & 4.9 \\
5 & Br Rea & 49 & 2.9 & $141,000,000$ & 2.4 \\
6 & Br Ene & 31 & 1.8 & $89,000,000$ & 1.5 \\
7 & Tano & 209 & 12.3 & $665,000,000$ & 11.5 \\
8 & Seteluk & 1696 & 100 & $5,778,000,000$ & 100 \\
\hline \multicolumn{7}{l}{ Total } &
\end{tabular}

Sumber: Laporan realisasi program keuangan mikro YOP (diolah)

program, dimana pada YOP Jilid I mekanismenya lebih sederhana dan unsur yang terlibat dalam memutuskan lebih sedikit dibandingkan YOP Jilid II. Perbedaan mekanisme dan pola penentuan nasabah tersebut menjadi turut menentukan hasil atau capaian program. Sebelum 2011, YOP menjalankan beberapa program tidak hanya bidang ekonomi, tetapi juga bidang lain, seperti penjelasan salah seorang mantan koordinator program berikut ini:

"Sebenarnya YOP ini menjadi mitra PTNNT dalam program pemerdayaan. Salah satu program yang paling terkenal yaitu bantuan modal usaha selain ada juga program pertanian seperti bantuan sarana produksi, hand traktor, peternakan, kehutanan dan lain sebagainya."(ANs 2014)

Saat ini YOP fokus pada dua program pokok, yaitu Keuangan Mikro dan unit bisnis dan pengembangan. Keuangan Mikro ditujukan untuk misi pemberdayaan masyarakat, sedangkan unit bisnis dan pengembangan ditujukan sebagai fundrising bagi kemandirian dan keberlanjutan YOP.Hal ini diperkuat oleh pernyataan salah seorang Pengurus YOP, sebagai berikut :

"Yayasan ini dulunya belum fokus ke Keuangan Mikro. Yayasan ini bergerak di semua elemen (bidang). Kemudian sejak 2011 kami baru konsentrasi untuk mengurus Keuangan Mikro YOPini."'(NSl 2014).

Penegasan tentang Keuangan Mikro sebagai program andalan YOP juga dijelaskan oleh PL YOP sebagai berikut:

"Sebenarnya Keuangan Mikro YOPini sudah berjalan lama beriringan dengan Alsintan (Alat Mesin Pertanian). Namun semenjak tahun 2010 banyak program lain yang dianggap tidak efektif. Akhirnya jatuhlah pilihan kepada Keuangan Mikro yang jauh efektif dan bisa dikontrol/ diawasi"..(RSd 2014)
Tabel 4. Realisasi program keuangan mikro per desa di kecamatan Sekongkang tahun 2011-2014

\begin{tabular}{lcccc}
\hline \multicolumn{1}{c}{ Desa } & $\begin{array}{c}\text { Jumlah- } \\
\text { realisasi } \\
\text { (kali) }\end{array}$ & \% & Nilai (Rp) & \% \\
\hline $\begin{array}{l}\text { Sekongkang } \\
\text { A }\end{array}$ & 63 & 16.7 & $275,500,000$ & 16.7 \\
$\begin{array}{l}\text { Sekongkang } \\
\text { B }\end{array}$ & 68 & 18 & $329,000,000$ & 19.9 \\
Kemuning & 42 & 11.1 & $187,500,000$ & 11.3 \\
Tongo & 59 & 15.6 & $228,500,000$ & 13.8 \\
Ai & 97 & 25.7 & $414,500,000$ & 25.1 \\
Kangkung & 48 & 12.7 & $219,500,000$ & 13.3 \\
Tatar & 377 & 100 & $1,654,500,000$ & 100 \\
\hline Total & & & & \\
\hline & & & & \\
\hline
\end{tabular}

\section{Program Keuangan Mikro YOP}

Definisi. Keuangan Mikro YOP adalah pembiayaan modal kerja dan investasi yang diberikan kepada pelaku usaha mikro guna pembiayaan usaha produktif dengan tujuan untuk meningkatkan akses usaha mikro terhadap dana pinjaman untuk pembiayaan investasi dan modal kerja dengan persyaratan yang ringan dan terjangkau (SOP Keuangan Mikro YOP).

Prosedur Permohonan. Secara singkatprosedurpermohonan program Keuangan Mikro YOPdapat digambarkan sebagai berikut (Gambar 4) :

Gambar 4 menunjukkan alur permohonan program, dimulai dengan calon debitur atau nasabah mengajukan permohonan ke bagian Admin Pembiayaan dengan hanya melapirkan foto copy KTP/ SIM. Admin Pembiayaan melakukan analisis awal. Hasil analisis awal diajukan ke bagian oprasional pembiayaan untuk dilakukan survey. Hasil survey dibahas dalam rapat Komite Pembiayaan yang akan mememutuskan apakah permohonan diterima atau ditolak.

Pembinaan dan Pengawasan Pembinaan dan pengawasan dimaksudkan untuk (1) menjamin agar penggunan dana nasabah sesuai dengan tujuan serta rencana pemberian, (2) memonitor kegiatan nasabah dalam mengelola usaha, (3) mengidentifikasi permasalahan yang timbul dalam kegiatan operasinya, (4) melihat sejauh mana kemungkinan adanya perubahan-perubahan terhadap ketentuan atas fasilitas pembiayaan tersebut, dan (5) menciftakan kondisi pelayanan optimal.

PadaYOPjilidIpembinaandanpengawasanmencakuppengelolaan angsuran nasabah dan pengembangan kapasitas. Sedangkan pada YOP jilid II difokuskan pada upaya pengembangan kapasitas usaha nasabah. Idealnya upaya pembinaan dan pengawasan akan 


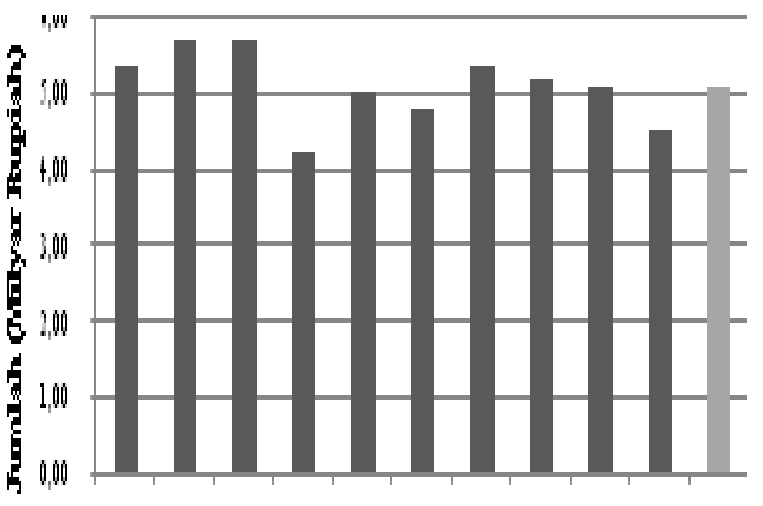

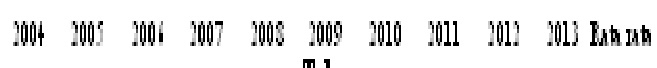
Tahum

Gambar 5. Grafik jumlah dana TJS PTNNT melalui YOP tahun 2004-2013

lebih efektif mengingat beban tanggung jawab petugas lapangan menjadi berkurang akan tetapi faktanya fungsi ini tidak berjalan oftimal dikarenakan kapasitas sumberdaya manusia yang terbatas.

\section{Realisasi dan Manfaat Keuangan Mikro YOP}

Tahun 2011-2013, YOP telah merealisasikan dana TJS PTNNT sebesar Rp. 5,8 milyar kepada 1.696 nasabah keuangan mikro yang tersebar di delapan kecamatan yang ada di KSB, dengan distribusi seperti pada Tabel 3. Dalam Tabel 3 tergambar bahwa Kecamatan Sekongkang mendapat alokasi terbesar (28,6\%). Dari persfektif TJSP, hal tersebut dapat dipahami karena lokasi PTNNT berada dalam wilayah kecamatan tersebut.

Fakta-fakta di atas menunjukkan bahwa Keuangan Mikroyang dikelola YOP selama ini berjalan dengan baik dan sesuai kaidahkaidah atau konsep Keuangan Mikro yang diperkenalkan oleh beberapa tokoh ekonomi dan dijalankan oleh lembaga keuangan mikro lainnyadengan segala kelebihan yang dimilikinya.Hal ini sesuai dengan pernyataan yang disampaikan oleh tokoh masyarakat yang juga mantan kepala desa sebagai berikut:

"Saya melihat program Keuangan Mikro sudah tepat sasaran.Saya melihat nasabahnya adalah orang yang benar-benar layak menerima program ini. Saya tidak melihat adanya nasabah YOP yang memiliki gaji tetap. Mereka benar-benar orang yang membutuhkan modal untuk usaha”. (MYn 2014)

Lebih lanjut ditegaskan bahwa:

"Saya melihat masyarakat sangat membutuhkan program ini karena keperluan akan modal usaha itu memang masih menjadi prioritas. Apalaigi ini sifatnya bergulir dan ada peningkatan secara kuantitas pada besaran modal di setiap tahunnya" (MYn 2014).

Pernyataan tersebut diperkuat oleh salah seorang kepala desa di Kecamatan Sekongkang sebagai berikut:

"Kalau dana hibah yang dikelola (oleh YOP) dalam bentuk revolving memang sangat dirasakan oleh masyarakat terutama pedagang bakulan, kios-kios

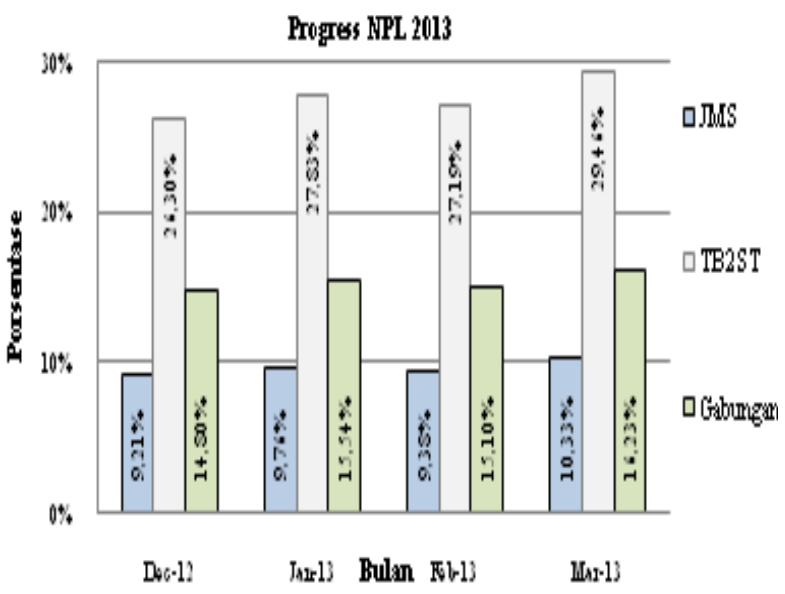

Gambar 6. Grafik NPL JMS dan TB2ST

yang sejauh ini kita pantau Alhamdulillah dirasakan sekali manfaatnya." (RTn 2014)

\section{Unit Bisnis dan Pengembangan}

Seperti penjelasan sebelumnya bahwa Divisi Unit Bisnis dan Pengembangan ditujukan bagi upaya kemandirian dan keberlanjutan YOP dengan ruang lingkup sebagai berikut:

a) Menyelenggarakan penguatan kapasitas bagi nasabah;

b) Menyelenggarakan penguatan kapasitas staf;

c) Melakukan analisis dan studi terhadap rencana pembentukan unit usaha yang dikelola YOP;

d) Memastikan bahwa unit usaha yang telah ada,dapat eksis dan berkembang dengan orientasi profit;

e) Melakukan monitoring dan evaluasi (monev) program;

f) Infodokom, yaitu melakukan kegiatan yang berkaitan dengan penyampaian informasi kegiatan lembaga, baik internal maupun eksternal melalui alternatif media yang dipakai seperti: buletin, media visual/elektronik, sosialisasi, monitoring dan lain sebaginya.

\section{Isu-isu Strategis}

\section{Pengelolaan Kelembagaan}

Salah satu tantangan terbesar YOP adalah terkait manajemen kelembagaan sehingga dapat memenuhi espektasi stakeholdersnya, seperti pemaparan pendamping YOP berikut:

\begin{abstract}
"Bagi Newmont, mereka tidak memerlukan uang, mereka hanya membutuhkan reputasi. Newmont tidak mencari untung dari program ini karena uangnya tidak kembali ke Newmont.Namun jika dilihat dalam skala makro, semua pihak diuntungkan.Jika program ini bagus, PTNNT juga senang, masyarakat penerima modal juga senang dan karyawan YOP juga senang karena mereka dapat penghasilan melalui program ini." (YId 2014).
\end{abstract}

Disatu sisi, pendamping mengakui bahwa eksistensi YOP memberikan "keuntungan" bagi banyak pihak, namun disisi lain tersirat sebuah pertanyaan tentang status YOP di 
Non Performing Loan (NPL)

Kurang lancar

Diragukan

Macet

1. Geografis yang jauh dari kantor pelayanan PT POS

2. Sistem PT POS yang masih manual (belum on line system)
1. Siklus perputaran uang 1. Suami nasabah terkena di PHK,

2. Belum panen (jenis usaha pertanian)

3. Terkena musibah

(meninggalnya anggota 3. Terkena musibah (kebakaran), keluarga)

4. Nasabah pulang kampung dan tidak meninggalkan aset (nasabah dari luar KSB).

2. Pulang kampung dan tidak kembali (Nasebelumnya lancar),

4. Faktor keluarga (perceraian),

5. Perizinan usaha yang tidak keluar,

6. Nasabah meninggal dunia ("diputihkan"; sabah berasal dari luar KSB, pembayaran ahli waris tidak perlu menanggung beban utang),

7. Provokasi pihak tidak bertanggung jawab agar nasabah tidak perlu membayar,

8. Peralihan usaha (pergantian jenis usaha dan pengalihan pengelolaan),

9. Piutang yang besar (modal usahanya yang belum besar dihutangkan dan macet),

10. Usaha yang dibiayai MF merupakan satu-satunya sumber pendapatan keluarga.

Sumber: Hasil in-depthinterview dan FGD (diolah)

mata PTNNT, seperti pemaparan berikut:

"Secara kelembagaan saya tidak mengetahui persis dimana posisi YOP di NNT.Karena di PTNNT itu tidak ada secara jelas hubungan kedudukan YOP di PTNNT".(YId 2014).

Kejelasan status inipentingbagiYOP, agardapatmenentukan strategi bagi kemandirian dan keberlanjutannya. Hal lain tentang kelembagaan YOP adalah terkait "kepentingan safety" PTNNT, seperti penyataan mantan koordinator YOP berikut:

"Pertama saya masuk YOP itu saya kaget karena saya ditemui oleh beberapa orang untuk meminta program atas rekomendasi petinggi PTNNT. Kesan saya saat itu YOP ini didirikan untuk "Pemadam Kebakaran", dan itu yang saya ingin rubah...”(ANs 2014).

Fakta-fakta tersebut dapat diinterpretasikan bahwa kebijakan PTNNT terhadap YOP menjadi salah satu faktor yang paling berpengaruh terhadap pengelolaan kelembagaan YOP. Sebagai sebuah lembaga yang otonom, seyogyanya YOP sudah bisa menentukan posisinya sendiri terhadap perusahaan.

\section{Reformasi Manajemen Kelembagaan YOP}

Mencermati kondisi kelembagaan yang ada, pada tahun
2011 diadakan "reformasi" manajemen kelembagaan YOP sebagai tindaklanjut dari hasil evaluasi partisipatif yang menghasilkan pembenahan/ perubahan pada beberapa aspek kelembagaan, yaitu administrasi, sumberdaya manusia, pengeloaan anggaran, pembenahan unit bisnis strategis, dan program keuangan mikro.

Bidang administrasi. Pembenahan dilakukan pada aspek administrasi keuangan dan umum.Pada YOP jilid I praktek pengelolaan keuangan cendrung dilakukan secara manual dan belum mempunyai SOP yang jelas. Pada YOP jilid II praktek tersebut dirubah, menggunakan kaidah-kaidah pengelolaan keuangan yang akuntable dan transparan dengan mengacu kepada SOP yang jelas dan admistrasi yang tertib (Tabel 5 pada lampiran)

Bidang sumberdaya manusia. Upaya peningkatan kompetensi dan keterampilan staf menjadi salah satu fokus pengembangan yang dilakukan YOP jilid II secara lebih terprogram melalui training, job-assignment, job-enrichment, job-enlargement. Selanjutnya, dilakukan penyesuaian pengupahan melalui penerapan standar dan skala pengupahan berbasis job description yang lebih proporsional.Hal berikutnya yang dikembangkan pada YOP jilid II adalah penyusunan sistem evaluasi dan penilaian kinerja staf(Tabel 6 pada lampiran).

Konsen lain terkait pengembangan Sumberdaya manusia adalah kepengurusan YOP. Pendapat salah seorang 
tokoh berikut menarik dicermati dan menjadi salah satu “tantangan” yang perlu dituntaskan YOP:

“...secara struktur, menurut saya perlu ada regenerasi tingkat top leadernya. Harus dicari orang-orang yang lebih kompeten di bidang itu karena selama ini hanya orang-orang itu saja yang memimpin.Pengurus yang ada saat ini rata-rata sudah umuran saya yakin kemampuan dan kecerdasannya pasti menurun. Kenapa tidak dicari yang masih muda dan agresif"' (URh 2014).

Bidang anggaran dan kegiatan. Pada bidang anggaran dan kegiatan program, perubahan mendasar yang dilakukan oleh YOP jilid II adalah terkait sistem perencanaan anggaran.Pada YOP jilid I alokasi anggaran didasarkan pada proposal yang diterima dari masyarakat dan berbasiskan kuota wilayah.Pada YOP jilid II, pola tersebut dirubah menjadi berdasarkan kebutuhan dan goal/ target tahunan berbasis kelayakan usaha. Berikutnya adalah item (pos) anggaran yang terlalu banyak pada YOP jilid I dirasionalisasikan menjadi proporsional dan efisien. Alokasi anggaran untuk program dan unit bisnis dilakukan pemisahan pada YOP jilid II dimana sebelumnya alokasinya digabung menjadi satu (Tabel 7 pada lampiran).

Program keuangan mikro. Proses pembenahan diawali dengan evaluasi terhadap keseluruhan program yang dijalankan YOP selama ini dan pola pelaksanaannya. Proses evaluasi dilaksanakan secara partisipatif oleh tim internal (Pengurus dan staf) YOP yang difasilitasi oleh pendamping PTNNT yang kemudian memutusksn bahwa YOP akan fokus pada program Keuangan Mikro serta unit bisnis dan pengembangan. Hal mendasar lain yang berubah adalah pola pengelolaan keuangan nasabah program. Pada YOP jilid I, transaksi keuangan nasabah (pencairan dan pengembalian angsuran) dilakukan oleh YOP secara langsung. Pola seperti ini, telah teridentifikasi sebagai salah satu penyebab NPL.Oleh karenanya pada YOP jilid II, pendekatannya dirubah dengan menggunakan perantara pihak ketiga yaitu PT POS Indonesia. Pola ini mendatang keuntungan lain bagi YOP, yaitu menjadi lebih fokus pada upaya pendampingan dan penguatan kapasitas nasabah (Tabel 8 pada lampiran).

Unit bisnis strategis.Selanjutnya, YOP jilid II telah mulai memikirkan upaya kemandirian dan keberlanjutan. Untuk itulah fokus program YOP jilid II, selain program Keuangan Mikro, juga mengembangkan unit bisnis sebagai profit center (Tabel 13) dimana salah satu fungsinya adalah mengembangkan fund rising dengan harapan YOP dapat membiayai dirinya sendiri. Air Minum Dalam Kemasan (AMDK) Pola Mata merupakan salah satu unit bisnis yang dikembangkan .Selain itu, Koperasi Serba Usaha (KSU) Jajong Mandiri juga dikembangkan. Dalam perjalanannya kedua unit bisnis ini menghadapi berbagai kendala sehingga tidak bisa berkembang seperti Harapan (Tabel 9 pada lampiran).

\section{Pendanaan YOP (Kelembagaan dan Program)}

Sampaisaatini, sumberpendanaanYOPhanyamengandalkan
PTNNTtermasuk Keuangan Mikro. Ketiadaan sumber pendanaan selain PTNNT pada prinsipnya merugikan posisi YOP sebagai lembaga pelaksanaDalam konteks program, semakin besar atau berkembang sebuah program, tentu semakin besar pula dana yang dibutuhkan. Besaran danaTJS PTNNT yang disalurkan melalui YOP setiap tahunnnya rata-rata sebesar Rp. 5 milyar .

Dari sisi jumlah, anggaran tersebut relatif besar bagi sebuah LSM lokal yang hanya fokus menjalankan dua program. Dari sisi pemberdayaan masyarakat, angka yang relatif besar tersebut, tidak selalu berbanding lurus dengan efektifitas penggunaanya, seperti pandangan salah seorang Kepala Desa berikut:

“Oknum PTNNT juga menikmati dana YOP tersebut. Sehingga mereka saling melindungi. Mungkin saja ada kepentingan lain selain uang, misalnya urusan tanah dan lain sebagainya akan tetapi saya tidak tahu. Kalau ada demo, preman-preman itu ngambil uang dari YOP. Apalagi di tahun 2005 gencar-gencarnya orang demo ke PTNNT dan uang itu diambil dari uang program yang semestinya digulirkan ke masyarakat" (HSn 2014).

\section{Pembiayaan Bermasalah}

Bila dilihat dari tingkat kolekabilitas, nasabah YOP dibagi menjadi dua ketegori yaitu nasabah dengan kategori lancar dan bermasalah.

Nasabah Lancar. Golongan ini umumnya mempunyai usaha yang berjalan lancar dan berkembang bahkan melakukan diversifikasi usaha, mempunyai karakter bagus, biasanya telah memperoleh pinjaman beberapa kali,mendapatkan pelatihan kewirausahaan, manajemen usaha, dan manajemen rumah tangga (Tabel 10 pada lampiran).

Pembiayaan bermasalah atau Non Performing Loan (NPL), adalah pembiayaan yang kolektabilitasnya berada pada kondisi kurang lancar, diragukan, dan macet. Besaran NPL dihitung dari penjumlahan 50\% dari pembiayaan dan atau tagihan kurang lancar, 75\% daripembiayaan dan atau tagihan diragukan, dan 100\% dari pembiayaan dan tagihan macet. Perhitungan NPL YOP dilakukan menggunakan formulasi berikut.

$$
\text { NPL }=\frac{\text { Kurang lancar }+ \text { Diragukan }+}{\text { Macet }} \times \frac{100 \%}{\text { Total pinjaman yang diterima }}
$$

Menurut Laporan Perkembangan Keuangan Mikro YOP Per 31 Maret 2013, hingga akhri Maret 2014padadelapan kecamatan di seluruh KSB, tingkat NPL rata-rata sekitar 16\%. Jika dilihat per area Lingkar Tambang (Kecamatan Jereweh, Maluk, dan Sekongkang, biasadisingkat JMS) dan Non-Lingkar Tambang (Kecamatan Taliwang, Brang Rea, Brang Ene, Seteluk, dan Poto Tano, biasadisingkat TB2ST) maka akan kelihatan bahwa area Non-Lingkar Tambang tingkat NPL-nya jauh lebih tinggi dibandingkan area Lingkar Tambang (Gambar 6). 
Tabel 13. Karakteristik tahap-tahap kedermawanan sosial

\begin{tabular}{llll}
\hline \multicolumn{1}{c}{ Paradigma } & \multicolumn{1}{c}{ Charity } & \multicolumn{1}{c}{ Philantrophy } & \multicolumn{1}{c}{ Good Corporate Citizenship (GCC) } \\
\hline Motivasi & $\begin{array}{l}\text { Agama, } \\
\text { tradisi, } \\
\text { adaptasi } \\
\text { Misi }\end{array}$ & $\begin{array}{l}\text { Norma, etika, dan } \\
\text { hukum universal }\end{array}$ & Pencerahan diri \& rekonsiliasi dengan ketertiban sosial \\
& $\begin{array}{l}\text { Mengatasi } \\
\text { masalah }\end{array}$ & $\begin{array}{l}\text { Mencari dan mengatasi } \\
\text { akar masalah }\end{array}$ & Memberikan kontribusi kepada masyarakat \\
Pengelolaan & $\begin{array}{l}\text { Jangka } \\
\text { pendek, } \\
\text { mengatasi } \\
\text { masalah } \\
\text { sesaat }\end{array}$ & $\begin{array}{l}\text { Terencana, terorganisir } \\
\text { dan terprogram }\end{array}$ & Terinternalisasi dalam kebijakan perusahaan \\
Kepanitiaan & $\begin{array}{l}\text { Yayasan/dana abadi/ } \\
\text { profesionalitas } \\
\text { Pengorganisasian }\end{array}$ & Keterlibatan baik dana maupun sumberdaya lain \\
Penerima manfaat & $\begin{array}{l}\text { Orang } \\
\text { miskin }\end{array}$ & Masyarakat luas & Masyarakat luas dan perusahaan \\
Kontri busi & $\begin{array}{l}\text { Hibah } \\
\text { sosial }\end{array}$ & Hibah pembangunan & Hibah (sosial \& pembangunan serta keterlibatan sosial) \\
Kewajiban & Kepentingan bersama & \\
\hline Sumber: Saidi (2003) & dalam Ambadar (2008) &
\end{tabular}

\section{Pendampingan Kelembagaan}

Pola pendampingan PTNNT terhadap YOP merupakan salah satu pembeda dengan pola kemitraan PTNNT dengan mitra program lainnya.Peran pendamping pada lembaga/ program lainhanya sebatas pendampingan, pengawasan, dan pembinaan. Namun peran pendampingan di YOP/ Keuangan Mikro, selain sebagai pendamping, juga menjalankan peran manajer meskipun tidak memiliki kedudukan langsung dalam struktur kepengurusan YOP, seperti pemaparan pendamping berikut:

"Saya di YOP hanya sebagai pendamping. Memang secara ekplisit saya tidak diberikan tugas yang jelas di YOP. Namun yang saya pahami saya harus melakukan pembenahan internal YOP" (YId 2014).

Reformasi kelembagaan yang dilakukan oleh YOP Jilid II merupakan bagian dari hasil kerja yang dilakukan oleh tim pendamping. Meskipun eksistensi pendamping telah membawa perubahan yang signifikan bagi kelembagaan dan program Keuangan Mikro. Untuk menjadi sebuah lembaga yang mandiri dan berkelanjutan seyogyanya YOP menyiapkan phase out/ exitstrategy. Selain penataan organisasi, program dan aset,pendamping jilid II juga membuat jadwal pertemuan rutin sebagai media komunikasi dan penyelesaian masalah yang dihadapi selama pelaksanaan program yang pada jilid I tidak pernah dilaksanakan. Hal ini menjadi penting dalam rangka transparansi dan melibatkan semua pihak dalam menjalankan program sehingga terjalin kohesivitas dalam tim kerja.

Pengawasan yang dilakukan oleh tim pendamping dilakukan secara sistematik mengikuti alur manajemen pengawasan sehingga menghasilkan hasil pengawasan yang maksimal seperti yang dirasakan oleh pengurus YOP dan masyarakat.
Keberadaan tim pendamping ini diapresiasi oleh salah seorang staf YOP berikut:

"Dalam pengambilan keputusan internal yang lebih banyak berperan itu adalah pengurus YOP, namun berkonsultasi dengan pendamping.Pada setiap rapat juga masih didominasi oleh pengurus.Namun kalau saya lihat, peran pendamping itu 50:50 dengan pengurus.Hal ini mungkin karena dananya bersumber dari PTNNT sehingga peran pendamping itu cukup signifikan. Saya juga berharap agar kami juga bisa terus didampingi karena sejauh ini kami sangat merasakan manfaat dari keberadaan mereka” (EKn 2014).

Apresiasi serupa juga disampaikan oleh salah seorangKepala Desa di wilayah Kecamatan Sekongkang;

"Mereka sangat profesional.Mereka sangat membantu masyarakat saya karena di sini memang banyak pedagang bakulan dan asongan.YOP juga komit dengan peningkatan jumlah modal usaha jika nasabahnya aktif membayar"(RTn 2014).

Apresiasi terhadapkinerja timpendampingyang memperkuat posisi dan kinerja pengurus dan pengelola Keuangan Mikro YOP tersebut tentu tidak berbanding lurus dengan fakta YOP jilid I. Pada fase YOP Jilid I manajemen operasional program belum berjalan dengan maksimal. Selain masalah manajemen, YOP juga mengalami krisis orientasi program.

Pendampingan yang dilakukan oleh PTNNT terhadap kelembagaan dan program yang dilaksakan oleh YOP sejatinya telah dimulai sejak awal YOP bermitra dengan PTNNT. Pendampingan yang dilakukan bertujuan untuk memastikan program berjalan efektif dan efisien. Namun karena cakupan program yang dijalankan oleh YOP Jilid I saat itu begitu besar dan luas mengakibatkan fungsi 
pengawasan dan evaluasi tim pendamping menjadi tidak maksimal.

Indikator dari tidak maksimalnya pendampingan oleh PTNNT tersebut tercermin dari pelaksanaan program yang tidak fokus dan disorientasi program pernyataan tokoh masyarakat Sekongkang berikut:

"Peran dari pendamping YOP tidak optimal, saat itu saya tahu persis pendampingnya dari NNT untuk YOP juga bermain" (HSn 2014).

Fakta dan keterangan dari tokoh masyarakat tersebut dibenarkan oleh salah seorang Pendamping YOP,

"Saya mendampingi YOP itu sejak 2011.Berdasarkan diskusi dengan Pak Jarot dan Pak Arif (Pembina YOP dari unsur PTNNT) kita sepakat bahwa banyak hal yang harus dibenahi tentang YOP dan saya diberikan tugas untuk melakukan pembenahan tersebut. Banyak kesan negatif yang melekat di YOP, seperti banyak penyimpangan, kinerjanya kurang bagus dan persepsi masyarakat terhadap YOP juga jelek" (YId 2014).

\section{Jejaring dan Kemitraan}

Sebagaimana yang telah dijelaskan sebelumnya, bahwa kemitraan YOP dengan PTNNT telah berjalan cukup lama bahkan sejak berdirinya YOP. Namun sejauh ini pola kemitraannya menjalani dinamika.Kemitraan jilid I sudah dijelaskan pada bagian sebelumnya.Untuk kemitraan jilid II (2011 sampai saat ini) kemitraannya lebih profesional. Sebagaimana yang dijelaskan oleh salah seorang Pengurus YOP berikut:

"YOP adalah fasilitator. Kami diberi dana oleh PTNNT dalam menjalankan program yang kami buat. Kami juga ada kontrak kerja dengan PTNNT sama seperti lembaga lain Masa kontrak kami selama 1 tahun kemudian diperbaharui. Kami indipenden. Masa-masa awal berdirinya YOP itu memang tidak ada ikatan kontrak dengan PTNNT.Sejauh ini kami tidak ada masalah dengan pihak PTNNT karena Dewan Pembina dan Dewan Ketua itu adalah orang NNT seperti Pak Jarot itu juga menjadi pengurus YOP" (NRl 2014).

Pola kemitraan jilid II ini memang dianggap lebih baik dari sebelumnya.Intervensi dari pihak NNT juga sedikit demi sedikit berkurang. Dalam wawancara dengan pendamping YOP, dijelaskan bahwa PTNNT tidak bisa mempengaruhi kebijakan yang akan diambil oleh YOP,

"Secara internal memang itu (kebijakan) menjadi kewenangan mereka, sayajuga tidak bisa mengintervensi karena mereka juga independen" (YId. 2014).

Pola kemitraan yang baik ini tentu harus terus dievaluasi dalam rangka meningkatkan kinerja YOP sebagai mitra. Jika ini terus diperbaiki dan diperkuat, maka akan mendatangkan kebaikan pula bagi PTNNT, antara lain adalah persepsi negatif yang selama ini melekat pada YOP yang berdampak pada image PTNNT akan terus berkurang dan masyarakat akan menilai pelaksanaan program dan kelembagaan YOP adalah profesional dan murni untuk pengembangan dan pendampingan masyarakat miskin.

\section{Kemandirian dan Keberlanjutan}

Tantangan terbesar yang dihadapi YOP saat ini adalah terkait kemandirian dan keberlanjutan. Kedua isu ini hendaknya menjadi prioritas untuk dituntaskan. Hal ini akan mempengaruhi persepsi masyarakat terkait kapasitas dan kredibelitas YOP dalam menjaga eksistensi kelembagaan dan keberlanjutan program yang dijalankan.

Kemandirian. Adalah salah satu isu sentral yang muncul danberkembang ditengahmasyarakat.Sebagianmasyarakat meragukan kemampuan YOP secara kelembagaan untuk tetap bertahan tanpa dukungan finansial dari PTNNT. Hubungan yang kuat dan cenderung "parasitisme" dengan PTNNT menjadi salah satu alasannya. Alasan lain adalah bahwa YOP (Jilid I) dijadikan "alat" oleh PTNNT dalam rangka meredam gejolak sosial yang terjadi di masyarakat akibat resistensi terhadap keberadaan PTNNT. Hal ini terungkap saat wawancara dengan tokoh masyarakat Sekongkang, sebagai berikut:

"Mungkin PTNNT merasa bahwa keberadaan YOP untuk meredam persoalan sosial dan menurut PTNNT ini penting.dan saya yakin PTNNT butuh keamanan sosial dan ini dilakukan oleh YOP" (MTr 2014).

Pendapat yang sama juga disampikan oleh tokoh masyarakat lain yang juga mantan koordinator program YOP Kecamatan Sekongkang:

"Saya melihat ada simbiosis mutualismenya. Di satu sisi PTNNT melihat YOP bisa menjalankan program pemberdayaan masyarakat (namun di sisi lain) ada misi peredam (pengaman operasional perusahaan)" (ANs 2014).

Selain isu simbiosis mutualisme antara YOP dan PTNNT dalam misi-misi tertentu, isu kemandirin ini juga muncul akibat tata kelola kelembagaan dan keuangan YOP jilid I yang dianggap belum baik.Hal ini ditandai dengan masih kuatnya kebergantungan YOP terhadap PTNNT. Jika dalam 1 tahun PTNNT memberikan dana rata-rata sebesar Rp 5 milyar, maka idealnya jika dana tersebut dikelola dengan baik maka YOP sudah bisa mengakhiri ketergantungannya terhadap PTNNT. Kondisi tersebut juga dipertanyakan oleh salah seorang kepala desa di Kecamatan Sekongkang seperti kutipan berikut:

"Mestinya sejak tahun 2009 YOP sudah bisa mandiri. Lalu kenapa sampai saat ini belum mandiri?" (HSn 2014).

Pandangan senada dari tokoh masyarakat lain yang juga mantan kepala desa sebagai berikut ini:

"Saya tidak melihat transparansi dan manajemen kontrol program yang dijalankan YOP” (MTr 2014). 
Hubungan yang kuat antara PTNNT sebagai lembaga donor dengan YOP sebagai pelaksana program atas dana tersebut menjadikan posisi kedua belah pihak dalam dilema. Disatu sisi hubungan tersebut akan saling menguntungkan karena bagaimanapun juga YOP sebagai sebuah LSM membutuhkan relasi dalam rangka menjalankan misi sosialnya dalam hal pemberdayaan masyarakat. Namun di sisi lain akan menjadi boomerang jika tidak mampu beradaptasi dengan segala kepentingan lembaga donor yang tidak bersesuaian dengan misi yang diemban oleh YOP.

Hal ini tentu bertentangan dengan misi dan filosofi TJSP/ CSR itu sendiri.Sebagaimana definisi CSR Wibisono (2007). Menurutnya CSR sebagai tanggung jawab perusahaan kepada pemangku kepentingan untuk berlaku etis, meminimalkan dampak negatif dan memaksimalkan dampak positif yang mencakup aspek ekonomi sosial dan lingkungan (triple bottom line) dalam rangka mencapai tujuan pembangunan berkelanjutan. Demikian pula definisi ISO 26000: 2010 Guidance on Social Responsibility: CSR adalah tanggung jawab sebuah perusahaan atas dampak keputusan dan kegiatannya terhadap masyarakat dan lingkungan, melalui perilaku yang transparan dan etis yang berkontribusi bagi pembangungan berkelanjutan, kesehatan dan kesejahteraan masyarakat.

Dari kedua definisi tersebut, terdapat kata kunci dari pelaksanaan CSR yaitu prilaku etis. Oleh karenanya, perlu adanya pemilahan yang dikotomis antara misi CSR perusahaan dengan kepentingan "lain" perusahaan tersebut. Di sisi lain, jika YOP segera keluar dari ketergantungan dengan PTNNT maka lembaga ini akan segera mandiri dan memiliki posisi tawar (bergaining) terhadap perusahaan yang menjalankan CSR-nya.

Tantangan terbesar lainnya dalam isu kemandirian YOP adalah keberlanjutan ketersediaan dana dalam melakukan pelayanan Keuangan Mikro YOPsetelah dana TJS PTNNT tidak lagi diberikan. Sebagai perusahaan tambangpada satu masa PTNNT pasti akanberhenti beroperasi di Batu Hijau dan secara otomatis dana TJS akan berkurang dan bahkan berhenti.

Keberlanjutan. Selain isu kemandirian yang sudah dibahas sebelumnya, sebagian masyarakat masih pesimis akan keberlanjutan (sustainabilitas) programKeuangan Mikro yang dijalankan YOP sebagai amanat TJS PTNNT. Sustainabilitas kelembagaan dan program YOP menjadi isu sentral berikutnya yang berkembang.Idealnya, isu keberlanjutan ini harus dijadikan salah satu prinsip dari kegiatan program Keuangan Mikro YOP itu sendiri.Stressing point dari keberlanjutan terletak pada kemampuan lembaga (YOP) untuk tetap terus eksis, meskipun tanpa PTNNT. YOP hendaknya berorientasi pada tujuan fungsional menuju ke arah peningkatan perbaikan derajat kesejahteraan sosial masyarakat, tidak lagi pada kepentingan jangka pendek sebagaimana dijelaskan sebelumnya.

Pada umumnya, Lembaga Keuangan Mikro (LKM) seperti LKM milik pemerintah, LKM proyek, maupun LKM-LSM menghadapi persoalan mengenai keberlanjutan aktivitasnya.
Ketidakmampuan dalam menjaga keberlanjutan tersebut dapat disebabkan oleh beberapa faktor, seperti dialami Keuangan Mikro YOP, antara lain (1) ketergantungan terhadapdukungan, baik dari pemerintah maupun donor, (2) hanya merupakanproyek yang didesain untuk sementara waktu, (3) ketiadaan sistem keuangan mikro yang memadai, dan (4) ketidakmampuan beradaptasi dengan situasi pasar keuangan mikro yang ada.

Menghadapi tantangan tersebut, kiranya perlu diingatbahwa aktivitas keuangan mikro hanya akandapat memberikan kontribusi yang nyata terhadap UKM dan masyarakat miskin manakala pelayanan keuangan mikro yang diberikannya dapat berlanjut (Ismawan, 2003).Rendahnya kinerja lembaga keuangan mikro, terutama dapat dilihat dari aspek (1) rendahnya tingkat pelunasan kredit, (2) rendahnya moralitas aparat pelaksana, (3) rendahnya tingkat mobilisasi dana masyarakat (Martowijoyo, 2002). Kelemahan tersebut membawa konsekuensi kepada tidak berlanjutnya LKM yang terbentuk setelah program kegiatan yang ada selesai.

Isu keberlanjutan ini dianggap signifikan paling tidak didasari oleh beberapa faktor.Pertama, masih kuatnya persepsi masyarakat yang menganggap bahwa dana CSR yang dikelola oleh YOP adalah dana hibah yang tidak harus dikembalikan (revolving). Anggapan ini tentu akan mempengaruhi performa YOP terutama dari sisi pengembangan keuangan, sehingga berapapun dana yang digulirkan oleh YOP melalui program Keaungan Mikro tidak akan berkelanjutan akibat persepsi yang berkembang di masyarakat tersebut. Kedua, kegiatan bisnis (air bersih Pola Mata) YOP yang diharapkan menjadi penopang program pemberdayaan YOP juga dianggap gagal oleh masyarakat karena operasionalnya juga menggunakan dana program pemberdayaan. Ketiga, isu keberlanjutan ini pada prinsipnya bagian yang tidak terpisahkan dengan isu kemandirian. Oleh karenanya, jika YOP mampu mandiri maka isu keberlanjutan inipun akan otomatis terjawab.

Fakta dan fenomena yang YOP tersebut tentu masih jauh dari ekspektasi masyarakat akan kemanfaatan dana TJSP. Ambadar (2008) menyatakan CSR adalah sebuah konsep manajemen yang menggunakan konsep "triple bottom line" yaitu keseimbangan antara mencetak keuntungan, harus seiring dan berjalan selaras dengan fungsi-fungsi sosial dan pemeliharaan lingkungan hidup demi terwujudnya pembangunan yang keberlanjutan (sustainable).

Namun jika dilihat dari perspektif sifat CSR maka apa yang dijalankan oleh YOP selama ini masih mendapatkan justifikasi teroritik. Menurut Abidin et al (2003) misalnya sumbangan sosial perusahaan dapat dibagi dua berdasarkan sifatnya, yaitu karitas (charity) dan filantrophy.Karitas yakni memberi bantuan untuk memenuhi kebutuhan yang sifatnya sesaat, sedangkan filantropi yaitu sumbangan yang ditujukan untuk kegiatan investasi sosial atau kegiatan yang diarahkan pada penguatan kemandirian masyarakat.

Berikut merupakan tabel yang memuat karakteristik tahap-tahap kedermawanan sosial yang diungkapkan oleh Saidi (2003) dalam Ambadar (2008): 
Bedasarkan teori di atas, maka dapat dipastikan bahwa CSR yang dikelola oleh YOP saat ini masih bersifat karitas. Artinya PTNNT dan YOP memiliki kesepahaman bersama bahwa yang terpenting dana tersebut sampai kepada masyarakat terlepas dari kemanfaatan dengan tujuan sosial serta pemberdayaan masyarakat.

\section{Strategi pengembangan kelembagaan dan Program Keuangan Mikro}

Merujuk kepada hasil kajian dan pembahasan sebelumnya, maka disusun rencana strategis pengembangan kelembagaan dan program microfinance menggunakan Analisis SWOT melalui proses FGD.Strategi adalah ilmu dan seni dalam memanfaatkan sumberdaya yang ada untuk mencapai tujuan yang telah ditentukan (Kolopaking 2013). Proses diawali dengan identifikasikondisi faktor internal berupa kekuatan/ strength (S) dan kelemahan/ weakness (W) serta kondisi faktor eksternal berupa peluang/ opportunity (O) dan ancaman/ threats $(\mathrm{T})$ berikut:

\section{Kekuatan/ Strength (S)}

1. Sistem kelembagaan dan program mulai di tata (Renstra, SOP)

2. Memiliki program unggulan (Microfinance dan Bisnis Unit Strategis);

3. Memiliki donatur (funding) tetap, yaitu PTNNT;

4. Satu-satunya lembaga keuangan dengan skim pinjaman tanpa bunga;

5. Pengelolaan keuangan yang akuntabel karena di audit oleh akuntan publik;

6. Menggunakan pihak ketiga untuk transaksi keuangan;

7. Memiliki dana program yang kembali (revolving fund)

8. Memiliki aset relatif besar (kantor, tanah, kendaraan, dan potensi bisnis);

9. Memiliki fasilitas dan sarana kerja yang relatif memadai;

10. Memiliki SDM yang cukup secara kuantitatif;

11. Pengelolaan program microfinance YOP berpersfektif gender;

12. Adanya pendampingan dan pembinaan dari PTNNT;

13. Staf YOP fokus pada upaya pendampingan; dan

14. Memiliki (potensi) fund rising;

\section{Kelemahan/Weakness (W)}

1. Belum memiliki Grand Strategy dan Road Map pengembangan kelembagaan untuk kemandirian dan keberlanjutan (rencana jangka panjang);

2. Pengelolaan kelembagaan dan program microfinance YOP belum sepenuhnya menjalankan aturan yang ada (Undang-undang Yayasan, AD/ ART, dan Kode Etik);

3. Antara tugas Pengurus Yayasan dengan Pelaksana Programbelum ada pemisahan yang jelas (rangkap jabatan);

4. Peran dan fungsi Dewan Pengurus dan Pengawas belum optimal;

5. Eksistensi kelembagaan dan program microfinance YOPsangat tergantung padaPTNNT;

6. Sosialisasi kepada masyarakat danstakeholdersterkait kelembagaan dan program belum optimal;

7. Kapasitas SDM masih relatif rendah (kognitif);

8. Mindset dan budaya kerja SDM masih sebatas menjalankan rutinitas (afektif);

9. Rekrutmen staf lapangan (OP) belum sepenuhnya berbasis kompetensi dan profesionalitas;

10. Inovasi dan kreatifitas SDM dalam mendesain program masih minim;

11. Jejaring dan kemitraan masih lemah;

12. Penatalaksanaan Informasi, dokumentasi, dan komunikasi (Infodokom) masih lemah;

13. Masih ada kepentingan-kepentingan tertentu (antara lain politik) dalam pelaksanaan program YOP yang dilakukan oleh Pengurus maupun petugas lapangan;

14. Pendampingan, monitoring dan evaluasi program belum optimal;

15. Jumlah kredit bermasalah (Non Performing Loan/ NPL) relatif tinggi

\section{Peluang/ Opportunity (O)}

1. Memiliki funding tetap yaitu PTNNT;

2. Memiliki potensi sponsorship dan kemitraan lain selain PTNNT (pemerintah, perbankan, dan lembaga keuangan lain);

3. Memiliki potensi fund rising

4. Belum ada lembaga keuangan non bank lain yang memiliki aset dan omset sebesar YOP;

5. Masyarakat memiliki ekspektasi yang cukup besar terhadap eksistensi program microfinance

6. Memiliki jumlah nasabah Program Microfinance yang relatif besar;

7. Berkembangnya sektor perdagangan dan jasa selain pertanian (potensi pasar);

8. Membangun jejaring dan kemitraan dengan pihak ketiga baik pada aras lokal, regional, nasional, maupun internasional;

9. Pelibatan masyarakat/stakeholders dalam pengelolaan program

10. Adanya dukungan kebijakan Pemda KSB terkait pengembangan keuangan mikro

\section{Ancaman/ Threat (T)}

1. Ketidakpastian terkait keberlanjutan sponsorshipPTNNT (regulasi, isu lingkungan dan sosial, dan force major);

2. Persepsi masyarakat dan stakeholderstentang Program Microfinance adalah dana hibah;

3. Masih terdapat keinginan sebagian masyarakat/ stakeholders untuk membubarkan YOP;

4. Masih ada upaya provokasi dari oknum-oknum tertentu untuk "merusak" system/ program yang dibangun YOP;

5. Tumbuhnya kompetitor/ lembaga keuangan sejenis baru

6. Intervensi funding (PTNNT) terhadap kebijakan kelembagaan dan program tinggi;

7. Persepsi masyarakat dan stakeholders terhadap kelembagaan dan program microfinance YOPmasih negatif;

8. Masih rendahnya partisipasi masyarakat/ 
stakeholdersdalam pengelolaan program; dan

9. Perubahan kebijakan pemerintah terkait pengelolaan keuangan dan yayasan.

Selanjutnya, dilakukan proses penyusunan strategi dengan "mengawinkan" faktor internal dengan faktor eksternal sehingga melahirkan strategi Strength-Opportunity (SO), Strength-Threat (ST) dan Weakness-Opportunity (WO) dan Weakness-Threat (WT) berikut:

\section{Strategi SO}

1. Penguatan/ Pengembangan sistem kelembagaaan dan program melalui pembenahan internal (bonding strategy);

2. Penguatan/ pengembangan kelembagaan dan program unggulan (microfinance dan unit bisnis strategis) pengembangan jejaring dan kemitraan dengan pihak ketiga pada aras lokal, regional, nasional, maupun internasional (bridging strategy);

3. Penguatan/ pengembangan kelembagaan dan program unggulan (microfinance dan unit bisnis strategis) melalui pengembangan jejaring dan kemitraan dengan funding potensial (PTNNT, Perbankan, dana CSR selain PTNNT) (creating strategy);

4. Penguatan dan pengembangan unit bisnis strategis dengan memanfaatkan jejaring nasabah Program Microfinance;

5. Pengembangan skim pembiayaan program microfinance agar lebih inovatif dan adaptif dengan kebutuhan pasar;

6. Mengembangkan kerjasama dengan pihak ketiga (PT Pos Indonesia, Pebankan, Akuntan Publik) dalam pengelolaan keuangan (transaksi, dan audit);

7. Pengembangan dana program yang kembali (revolving fund) sebagai bagian dari upaya penguatan dan kemandirian kelembagaan (fund rising);

8. MemaksimaIkan potensi aset, kuantitas SDM, fasilitas dan sarana kerja yang memadai bagi pengembangan kelembagaan dan program microfinance;

9. Optimalisasi peran pendamping PTNNT dalam membangun kapasitas kelembagaan dan manajemen program;

10. Optimalisasi keterlibatan/ peran gender dalam pengelolaan program microfinance

11. Meningkatkan kapasitas SDM melaui pelatihan staf, on the job training (OJT) dan study banding;

\section{Strategi WO:}

1. Mendorong dan memastikan tatakelola dan manajemen kelembagaan dan program YOP berjalan sesuai aturan yang berlaku;

2. Penyusunan grand strategy dan road map pengembangan kelembagaan dan program terkait kemandirian dan keberlanjutan;

3. Optimalisasi peran dan fungsi Dewan Pengurus dan Dewan Pengawan dalam pengelolaan Yayasan;

4. Optimalisasi implementasi AD/ ART dan aturan internalnya dalam pengelolaan kelembagaan;

5. Mengurangi tingkat ketergantungan YOP terhadap PTNNT melalalui fund rising dan akses dana CSR perbankan serta membangun jejaring dan kemitraan dengan pihak ketiga pada aras lokal, regional, nasional, dan internasional;

6. Melakukan sosialisasi dan komunikasi intensif ke masyarakat dan stakeholders terkait kelembagaan dan program;

7. Meningkatkan kapasitas SDM melalui pelatihan, on the job training,job assignment, dan study banding

8. Merubah mind set dan budaya kerja SDM dari sekedar menjalankan rutinitas menjadi orientasi target;

9. Melakukan rekrutmen staf berdasarkan kompetensi dan profesionalitas;

10. Membangun image YOP dan program melalui pembenahan/ reformasi dan inovasi kelembagaan dan program;

11. Mengembangkan jejaring dan kemitraan;

12. Mengembangkan manajemen/penatalaksanaan informasi, dokumentasi, dan komunikasi;

13. Memastikan kelembagaan YOP dan Program Microfinance bebas dari kepentingan tertentu diluar misi pemberdayaan sebagai bagian dari CSR PTNNT;

14. Optimalisasi pendampingan, monitoring, dan evaluasi program;

15. Mengembangkan sistem informasi, dokumentasi, dan komunikasi sehingga bisa mendapatkan peluang di aras lokal, regional, nasional, dan internasional yang bisa diakses oleh masyarakat maupun lembaga lain melalui websate;

16. Optimalisasi kinerja program microfinance guna menurunkan angka Non Performing Loan (NPL)

\section{Strategi ST:}

1. Mendorong kemandirian YOP melalui pengembangan (revolving fund) dan unit bisnis strategis (fund rising), serta membangun jejaring/akses pendanaan darifunding selain PTNNT;

2. Membangun persepsi masyarakat terhadap kelembagaan dan program microfinance YOP melalui pendekatan, Komunikasi, Informasi, dan Edukasi (KIE);

3. Membuka akses dan mendorong partisipasi masyarakat dan stakeholders dalam pengelolaan program microfinance;

4. Optimalisasiperan sumberdayaCSRPTNNT(kemitraan, pendanaan, pendampingan) bagi pengembangan kelembagaan dan program; dan

5. Membangun komunikasi dengan PTNNT terkait terkait kebijakan kemitraan, pendanaan, dan pendampingan;

\section{Strategi WT:}

Mendorong Pengurus YOP untuk melaksanakan/ menegakkan ketentuan perundang-undangan dan aturan internal dalam pengelolaan kelembagaan dan program;

\section{KESIMPULAN DAN SARAN}

\section{Kesimpulan}

Secara umum pengelolaan kelembagaan YOP dibagi menjadi dua periode yaitu YOP Jilid I dan Jilid II. Pengelolaan YOP Jilid II lebih baik dibandingkan Jilid I, dibuktikan dengan adanya pembenahan manajemen kelembagaan dan program pada beberapa aspek, antara 
lain administrasi, sumberdaya manusia, anggaran dan kegiatan, Keuangan Mikro, dan unit bisnis strategis.

Kelembagaan YOP masih lemah dari sisi kemandirian, resiliensi, dan keberlanjutan, dibuktikan dengan tingginya tingkat ketergantungan terhadap PTNNT (pendanaan dan pendampingan), unit bisnis belum dapat dijadikan fund rising, masih lemah pada aspek kapasitas SDM, jejaring dan kemitraan, serta lemah dalam hal pengelolaan informasi, dokumentasi, dan komunikasi.

Program Keuangan Mikro YOP telah sesuai SOP, persyaratan ringan dan terjangkau, prosedur mudah, program tepat sasaran, sesuai kondisi, karakteristik dan kebutuhan, serta manfaatnya dapat dirasakan masyarakat. Tantangan program adalah masih tingginya persentase NPL, terbatasnya skim pembiayaan, dan aspek pendampingan/ penguatan kapasitas nasabah belum optimal.

\section{Saran}

Strategi pengembangan kelembagaan dan program Keuangan Mikro YOP hendaknya diarahkan pada upaya kemandirian, resiliensi, dan keberlanjutan melalui lima alternatif strategi sebagai berikut:

1. Membangun persepsi (image dan trust) "positif" masyarakat dan stakeholders terhadap kelembagaan dan program Keuangan Mikro melalui bonding dan bridging strategy, serta pendekatan Komunikasi, Informasi, dan Edukasi (KIE).

2. Mengurangi tingkat ketergantungan kelembagaan dan program Keuangan Mikro melalui pengembangan unit bisnis strategis, dan memperkuat serta mengembangkan creating/networking strategy untuk mendapatkan sumber pendanaan dari luar (blending financing).

3. Meningkatkan dan mengoptimalkan upaya pendampingan kelembagaan dan program Keuangan Mikro dalam rangka memperkuat kapasitas (capacity building) kelembagaan dan masyarakat.

4. Membuka akses dan mendorong partisipasi masyarakat dan stakeholders dalam pengelolaan program Keuangan Mikro.

5. Menyusun exit strategy dalam rangka kemandirian, resiliensi, dan kemandirian kelembagaan dan program Keuangan Mikro.

\section{DAFTAR PUSTAKA}

Ambadar J. 2008. CSR Dalam Praktik di Indonesia Jakarta: PT Gramedia

Archie BC. 1991. The Pyramid of Corporate Social Responsibility: Toward the Moral Management of Organizational Stakeholders. Business Horizons [Internet] . [diunduh 2014 Feb 8]. Tersedia http:// www.cbe.wwu.edu/dunn/rprnts.pyramidofcsr.pdf

Budimanta, A, Prasetijo, A., Rudito, B. (2004) Corporate Social Responsibility Jawaban Bagi Model Pembangunan Indonesia Masa Kini.ICSD. Jakarta

[CGAP] Consultative Group to Assist the Poor. 2014. Microfinance Gateway. [Internet]. [diunduh 2014 Mei 25]. Tersedia pada:http:// www. microfinancegateway.org/p/site $/ \mathrm{m} /$ template. rc/1.26.12263/\#1

[CGAP] Consultative Group to Assist the Poor. 2004. Key Principles of Microfinance [Internet]. [diunduh 2014 Jun 4]. Tersedia: http:// www. cgap.org/sites/default/files/CGAP-ConsensusGuidelines-Key-Principles-of-MicrofinanceJan-2004.pdf

Dyer J and Boyer D. 2004.Rural Financial Institutions: Restructuring and Post Restructuring Results. Case Study on The Agricultural Bank of Mongolia: From Insolvent State Bank to Thriving Private Bank.BASIC-CRSP and the World Council of Credit Unions, Inc.

Emilian E. 2009. Menulis Tesis dan Disertasi.Bandung: Alfabeta

Ismawan B. 2003. Kemandirian: Suatu Refleksi. Ekonomi Rakyat III: 2-3

Ife J. dan Tesoriero F. 2008.Communiy Development: Alternatif Pengembangan Masyarakat di Era Globalisasi. Yogyakarta: Pustaka Pelajar.

[ISO] the International Organization for Standarization 26000. 2010. Guidance on Social Responsibility.

Kottler, Phillip \& Lee, Nancy. 2005. Corporate Social Responsibility: Doing the Most Good for Your Company and Your Cause.New York: John Wiley and Sons, Inc.

Kolopaking LM et al. 2013. Desain Pengembangan Kawasan Minapolitan Percontohan Berbasis Industri Rumput Laut Kabupaten Sumbawa Barat, PSP3-IPB

Martowijoyo S. 2002. Dampak Pemberlakuan Sistem Bank Perkreditan Rakyat Terhadap Kinerja Lembaga Pedesaan. Artikel Th I No 5 Jurnal Ekonomi Rakyat.www.ekonomirakyat.org.

Maurer K. 2004. Bank Rakyat Indonesia: Twenty Years of Large Scale Microfinance, Global Learning Process for Scaling Up Poverty Reduction and Conference in Shanghai, May 25-27, 2004 [Internet]. [diunduh 2014 Juni 2]. Tersedia: http://www.microfinancegateway.org/gm/ document-1.9.25618/39319_file_55.pdf

Nasdian FT. 2014. Pengembangan Masyarakat. Jakarta: Yayasan Pustaka Obor Indonesia.

[PTNNT] PT. Newmont Nusa Tenggara.2009. Rencana Strategis 2009 - 2013 tentang Pengembangan Masyarakat di Kecamatan Maluk, Jereweh dan Sekongkang. Yogjakarta (ID): Polydoor.

[PTNNT] PT. Newmont Nusa Tenggara. 2013. Rencana Strategis Tanggung Jawab Perusahaan Tahun 2014 - 2018 Departemen Social Responsibility PTNNT

Robinson MS. 2001. The Microfinance Revolution: Sustainable Finance for the Poor [Internet]. [diunduh 2014 Mei 2]; 1 (23250). Tersedia: http://www-wds.worldbank.org

Sugiyono. 2010. Memahami Penelitian Kualitatif. Bandung: Alfabeta.

Suharto E. 2005. Membangun Masyarakat Memberdayakan Rakyat. Kajian Strategis Pembangunan Kesejahteraan Soasial dan 
Pekerjaan Sosial. Bandung: Refika Aditama.

Susetiawan. 2012. Implementasi CSR Dalam Arena

Civil Society: Antara Idealisme dan Realitas dalam

Corporate Social Responsibility: Komitmen untuk Pemberdayaan Masyarakat. Yogyakarta: Azzagrafika.

Soetomo 2009. Pembangunan Masyarakat Merangkai Sebuah Kerangka. Pustaka Pelajar. Yogyakarta

Suharto, Edi. 2006. Membangun Masyarakat Memberdayakan Rakyat: Kajian Strategis Pembangan Kesejahteraan Sosial dan Pekerjaan Sosial (edisi ke-2). Refika Aditama. Bandung. . 2007. Undang Undang No. 40 Tahun 2007 tentang Perseroan Terbatas. 2008. Undang Undang No. 20 Tahun 2008 tentang Usaha Mikro, Kecil, dan Menegah

Wibisono, Y. 2007. Membedah Konsep \& Aplikasi CSR, Gresik, Fascho Publishing.

[YOP] Yayasan Olat Parigi dan Transform. 2012. Laporan Penyusunan Rencana Strategis Yayasan Olat Parigi.

Zaman H. 2004.Microfinance in Bangladesh: Growth, Achievements, and Lessons, Global Learning Process for Scaling Up Poverty Reduction and Conference in Shanghai, May 25-27, 2004 [Internet]. [diunduh 2014 Jun 2]. Tersedia: http:// info.worldbank.org/etools/docs/reducingpoverty/ c a s e / $108 / \mathrm{fu} 11 \mathrm{c}$ a s e / B a n g lad e s h \% 20 Microfinance $\% 20$ Full\%20Case.pdf

Zubaedi. 2013. Pengembangan Masyarakat. Wacana dan Konsep. Jakarta: Kencana Prenada Group. 